\title{
The Educational Value of Student Design Competitions
}

\author{
Ralph O. Buchal \\ Department of Mechanical \& Materials Engineering \\ The University of Western Ontario \\ London, Ontario \\ rbuchal@eng.uwo.ca
}

\begin{abstract}
Multi-university student design competitions can be very effective in achieving desired learning objectives relating to the engineering design process, teamwork and leadership skills, and design communication. These interdisciplinary projects provide a highly motivating engineering challenge, and develop valuable practical skills. Students are typically involved for more than one year, so they experience more than one significant design iteration. Furthermore, the self-managed teams use informal mentorship and apprenticeship to develop technical and leadership skills. It is important that these projects be student-directed, with faculty in an advisory role only. In order to incorporate these projects into the design curriculum, innovative assessment methods may be required.
\end{abstract}

\section{Introduction}

Design is what distinguishes engineering from science, and recently there has been a renewed emphasis on improving design education. It is now recognized that Canada needs better design engineers to ensure continuing prosperity.

Large multi-university student design competitions have long been a feature of undergraduate life at engineering schools, but the educational value of these projects is often not fully appreciated. At many schools, these "megaprojects" are seen as strictly extracurricular activities, with limited educational value. This paper argues that student megaprojects can be very effective in achieving desired outcomes in engineering design education.

\section{Desired educational outcomes and learning objectives}

\section{CEAB and ABET Criteria}

In the United States, the Accreditation Board for Engineering and Technology (ABET) specifies the required educational outcomes for engineering programs as follows [1].

Engineering programs must demonstrate that their graduates have:

- an ability to apply knowledge of mathematics, science, and engineering

- an ability to design and conduct experiments, as well as to analyze and interpret data

- an ability to design a system, component, or process to meet desired needs

- an ability to function on multi-disciplinary teams

- an ability to identify, formulate, and solve engineering problems

- an understanding of professional and ethical responsibility

- an ability to communicate effectively

- the broad education necessary to understand the impact of engineering solutions in a global and societal context 
- a recognition of the need for, and an ability to engage in life-long learning

- $\quad$ a knowledge of contemporary issues

- $\quad$ an ability to use the techniques, skills, and modern engineering tools necessary for engineering practice.

The Canadian Engineering Accreditation Board (CEAB) regulates engineering programs in Canada. $\mathrm{CEAB}$ requires a significant capstone design experience, as described below [2].

Engineering design integrates mathematics, basic sciences, engineering science, and complementary studies in developing elements, systems and processes to meet specific needs. It is a creative, iterative and often open-ended process subject to constraints which may be governed by standards or legislation to varying degrees depending on the discipline. These constraints may relate to economic, health, safety, environmental, social or other pertinent interdisciplinary factors.

The curriculum must culminate in a significant design experience which is based on the knowledge and skills acquired in earlier course work and which preferably gives students exposure to concepts of team work and project management.

\section{Non-technical skills and competencies}

There is broad agreement that development of nontechnical, complementary skills is a critical part of engineering education. Furthermore, there is general agreement about which skills are required. The Society of Manufacturing Engineers (SME) identifies the competencies shown in Table 1.

Table 1. Desired professional competencies [3].

\begin{tabular}{|l|l|}
\hline $\begin{array}{l}\text { Professional } \\
\text { competency }\end{array}$ & Definition \\
\hline $\begin{array}{l}\text { Written } \\
\text { communication }\end{array}$ & $\begin{array}{l}\text { Is able to write specifications, } \\
\text { proposals, memos, and } \\
\text { management reports in formal and } \\
\text { informal communications to } \\
\text { various audiences }\end{array}$ \\
\hline
\end{tabular}

\begin{tabular}{|l|l|}
\hline $\begin{array}{l}\text { Professional } \\
\text { competency }\end{array}$ & Definition \\
\hline $\begin{array}{l}\text { Oral } \\
\text { / Listening }\end{array}$ & $\begin{array}{l}\text { Possesses skills in speaking, } \\
\text { presenting, listening, reading body } \\
\text { language, and empathy in formal } \\
\text { and informal situations with various } \\
\text { audiences. }\end{array}$ \\
\hline $\begin{array}{l}\text { Teamwork/ } \\
\text { working } \\
\text { offectively with }\end{array}$ & $\begin{array}{l}\text { Understands interpersonal skills, } \\
\text { giving/receiving feedback, conflict } \\
\text { resolution/consensus building, } \\
\text { working in teams, organizing and } \\
\text { facilitating meetings, taking } \\
\text { accountability for group } \\
\text { performance, appreciating diversity }\end{array}$ \\
\hline $\begin{array}{l}\text { Project } \\
\text { Management }\end{array}$ & $\begin{array}{l}\text { Understands goal setting, planning, } \\
\text { design of projects, and deployment } \\
\text { of personnel and resources. Could } \\
\text { manage task dependencies and } \\
\text { performance to schedule. Monitors. } \\
\text { Prioritizes. }\end{array}$ \\
\hline $\begin{array}{l}\text { Business Skills/ } \\
\text { Knowledge }\end{array}$ & $\begin{array}{l}\text { Understands customer focus, cash } \\
\text { perspective } \\
\text { calculations, cost estimation and } \\
\text { justification (including life-cycle } \\
\text { costing), risk analysis and } \\
\text { management, legal/regulatory } \\
\text { impacts, and ethics. }\end{array}$ \\
\hline $\begin{array}{l}\text { Understands problem formulation } \\
\text { and definition, root and multiple } \\
\text { causation analyses, alternative } \\
\text { generation and testing, solution } \\
\text { evaluation, solution validation, } \\
\text { knowledge management. }\end{array}$ \\
$\begin{array}{l}\text { diversity; is aware of variations in } \\
\text { approaches, how systems work in } \\
\text { different cultures, and globalization } \\
\text { of engineering disciplines. }\end{array}$ \\
\hline
\end{tabular}

A recent study of the Canadian auto industry [4] identifies more or less the same competencies, with the notable addition of visual communication skills including sketching and engineering graphics. 


\section{Practical knowledge}

Previous generations of engineering students typically developed practical, hands-on experience through informal "tinkering" on cars and other devices. Since World War II, engineering education has veered away from practical matters and increased emphasis on engineering science and analysis. Furthermore, today's students are rarely "tinkerers". This is exacerbated by the trend in high schools to stream university-bound students into "academic" programs, while tinkerers are streamed into "vocational" programs. As a result, many potential engineers go to college, or enter skilled trades. At the same time, engineering students come to university with virtually no practical skills or knowledge. The traditional engineering science curriculum does little to develop this knowledge, with the result that mechanical engineers graduate without knowing how to attach a gear to a shaft, not knowing how a planetary gear system works, or what a pillow block bearing is.

\section{The Engineering Design Process}

Many excellent texts now exist for teaching the engineering design process [5, 6, 7], and most schools have at least one course in engineering design in addition to a capstone project.

There is general agreement that a systematic design process should be taught and practiced. While details vary between authors, the general phases of a complete design project should include the following:

- Problem definition

- Concept generation

- Evaluation of alternatives

- Modeling and analysis

- Construction and testing

- Redesign (iteration)

\section{Essential elements for design projects}

Farr et al. [8] identified four essential elements for a successful capstone design experience:

- Real world problems

- Utilize a total design process
- Close non-technical competency gaps

- Utilize many analytical tools in a team based environment

A survey paper by Dutson et al. [9] identifies the following attributes of a good design project:

- Challenging

- Good chance for successful completion

- Common enough so that there is literature available

- Emphasize application of theory

- Involve engineering design work

- Meet specified standards and safety criteria

- Not involve proprietary information if industry is involved

\section{Types of Design Projects}

Dutson et al. [9] identified several types of projects used in teaching design, including:

- Hypothetical projects. With this approach, instructors pose a hypothetical design problem, which may have no practical value but which teaches design concepts. The scope can be easily managed, but the "reality" may be sacrificed.

- Industry projects. There is a growing trend toward seeking projects from industry, with industry sponsorship. These are "real" projects, but they can be difficult to manage and coordinate. Often the challenge is either too great or insufficient for a student team, and design content is hard to control.

- $\quad$ Student-defined projects. Students often have ideas they wish to pursue, and some instructors permit students to define their own project. This is most suitable for potential entrepreneurs and inventors.

- Design competitions. Many engineering societies sponsor major student design competitions involving dozens or even 
hundreds of schools. These competitions are well structured, with clear rules and deliverables. Most schools have teams active in at least one such competition.

\section{The case for design competitions}

Design competitions can have tremendous educational value in developing desired skills and competencies. However, to maximize these benefits, the ideal conditions need to be identified and maintained. This section describes the author's observations and experiences with design teams at Western. These teams include: Formula SAE race car, SAE Mini-Baja off-road vehicle, SAE Aero radio-controlled plane, and Sunstang solar car.

\section{Interdisciplinary teams}

Design competitions typically involve teams of two or three up to several dozen members. Teams are typically composed of students from different years and disciplines, including non-engineering disciplines. This is one of the only opportunities available to participate in a true interdisciplinary team.

Some teams also involve high school students, alumni, and interested members of the community. This promotes outreach, student recruiting, alumni relations, and community relations.

Most traditional capstone design projects are teambased as well, but the teams are usually quite homogeneous - students in the same year of the same program, with similar backgrounds. It is often difficult to establish interdisciplinary capstone design teams involving more than one department due to differing course requirement, etc.

\section{Motivation and dedication}

It is generally agreed that learning is maximized when students are motivated. Design competitions are highly motivating compared to other types of projects. Despite lack of formal academic credit for these projects at Western, student dedication and commitment is outstanding. There are many cases where students have delayed starting work by several months after graduation in order to complete projects and participate in competitions.

Motivation in traditional projects can be highly variable. Student motivation for projects they have chosen or defined themselves seems to be higher than projects that are assigned. This is a particular risk with industry projects.
While it can be argued that practicing engineers can't choose their own projects, the importance of motivation in maximizing learning cannot be overlooked.

\section{Self-directed and life-long learning}

Self-directed and life-long learning are important skills for engineers. The Western design teams typically learn what they need to know without formal instruction. This important skill is developed out of necessity, when students realize that they need certain knowledge to design a successful artifact. At Western, few faculty members have the specific expertise the students require. Also, the hands-off approach of faculty advisors means that students can't rely on the professor to provide all the necessary information.

Team members develop considerable expertise in various areas like suspension design, engine tuning and testing, materials, CAD modeling, etc. Much of this information is not covered in existing courses. Important sources of information include the Internet, part suppliers, industry contacts, books, research papers, teammates, previous designs, and designs of other schools.

\section{Mentorship, apprenticeship and leadership}

Many of the teams develop an informal system of mentorship and apprenticeship, with senior students mentoring junior students. Junior members typically progress to leadership positions after a year or two.

Traditional projects are not as rich in this respect, due to their relatively short duration. Team leaders may naturally emerge, or rotating leadership might be imposed by the instructor.

\section{Practical experience}

Student megaprojects provide an outstanding opportunity for students to develop practical, hands-on skills and experience to complement their formal education. The result is better engineers with both practical and theoretical knowledge. These attributes are highly prized in industry, and many employers look for this experience.

The practical nature of these projects supports experiential learning, and is well suited to all learning styles.

Traditional projects are variable in the practical experience gained. Many traditional projects are paper-based, or involve construction of crude prototypes only. 


\section{Self-managed teams}

At Western, the megaproject teams are student initiated and student managed. Students develop outstanding leadership and teamwork skills through these projects.

Faculty involvement is minimal, so project management is done by the students themselves. Each team establishes a management structure with an overall project manager, team leaders, etc. The leadership is typically shared and consensual rather than top down.

The self-managed nature of Western teams is a strength. Strong faculty involvement and management of the teams would greatly dilute this aspect. The role of faculty should be to encourage, coach and mentor, but not to control or manage.

With traditional capstone projects, the teams are typically managed by the course instructor. The current practice at Western is to have project teams of three students with rotating leadership, with overall coordination managed by course instructors and faculty advisors.

\section{Engineering challenge}

The level of engineering challenge of the design competition projects is significantly higher than most other student design projects done for credit. Competition rules require professional design documentation, and head-to-head competition between teams provides an objective measure of achievement.

Many schools devote significantly more resources to their teams than Western, so the level of competition is very high. It is expected for a well-supported team to do well; for an "underfunded" team to do well is a challenge, and an impressive accomplishment.

\section{Real-world design}

The UWO design teams typically progress through all stages of the design process, from conceptual design through construction, testing and iteration. Design iterations occur each year when the object is redesigned, taking into account experience from previous years.

While one might argue that a competition like Formula SAE does not solve a real-world problem, one could equally argue that motor racing represents the pinnacle of automotive engineering.

Many feel that only industry projects provide "realworld” engineering experience; however, industry projects often involve routine design and may lack challenge.

\section{Multi-year iterative design and improvement}

A survey by Dutson et al. [9] of 360 engineering departments showed that $97 \%$ of student projects were of one year duration or less. In contrast, many megaproject team members participate for more than one year, so there is significant continuity and students have an opportunity to experience at least one significant design iteration. This results in transfer of knowledge and continuous improvement from one year to the next. Designs are continuously improved based on the results of the competition and benchmarking against other teams.

Traditional projects last only one academic year at most, with no transfer of knowledge from one year to the next. Many projects never reach the prototype stage, let alone testing and redesign.

\section{Learning from failures}

Western megaproject teams often achieve disappointing results at competitions due to mechanical failures. These failures can be valuable learning experiences to improve future designs, as well as driving home the importance of testing in the design process.

\section{Experiences at other schools}

Student design competitions are incorporated into the design curriculum at many schools, and we can learn from these experiences.

Catalano and Tonso [10] describe the incorporation of the Sunrayce solar car competition into a senior capstone design course at the United States Military Academy. The instructors assigned 28 students to seven teams, each responsible for a different vehicle subsystem. The teams tended to work independently rather than collaboratively, despite attempts at coordination. The final paper design was thoroughly reviewed and critiqued by the faculty advisors before construction began. As the project fell behind schedule, faculty and staff became heavily involved in fabrication, relegating students to a secondary role. Student morale and commitment fell, and a survey of student satisfaction yielded mixed results. The instructors felt that this project required too much faculty effort and resources, and perhaps less ambitious projects should be attempted in the future.

Joseph Rencis [11] describes the Formula SAE racecar project at Worcester Institute of Technology. At WPI, 
most of the team is comprised of seniors, and they receive course credit for participation. Rencis notes that there is little continuity from year to year, and few students are willing to participate unless there is academic credit given. The team is comprised of mostly mechanical students, with two or three electrical students. Students are divided into different functional teams, with leaders assigned by the faculty advisor. Rencis recommends that "the advisor(s) play an active role, the project must be structured, deadlines must be established and firmly held to, and the car must be completed [in time for testing]". Rencis seems to believe that the faculty advisor must take a strong management role for the team to be successful.

The Western Formula SAE team has performed at least as well as WPI in recent competitions, without the kind of strong central management advocated by Rencis. Western's design teams have no problem maintaining high morale, and all students work on them without expectation of academic credit. Western students observe at competitions that some teams are clearly dominated by faculty and staff advisors, with students in a subservient role. Western teams are often unaccompanied by faculty advisors, and when advisors are present they do not dominate but simply provide encouragement.

Too much faculty involvement could actually hinder the learning experience. If faculty dominate the project by assuming responsibility for organizing the team, managing schedules, making design decisions, etc., the result can be a significant reduction in student commitment, morale, and learning. This suggests that student ownership and management of the projects is very important, and that faculty should stay on the sidelines.

\section{Outreach value}

Student megaprojects have significant outreach value in promoting engineering to the community, recruiting students, and maintaining links with alumni.

\section{Promotion of engineering}

Design competitions are newsworthy and attract great interest within the community. Many members of the community think of the design teams when they think of Western engineering. This publicity is invaluable in promoting engineering, and the design teams are at the forefront of formal and informal outreach activities.

\section{Student recruitment}

The design competitions excite high school students who may have misperceptions or lack of awareness regarding engineering as a profession. The design competitions have been a significant factor in many students' decisions to come to Western Engineering.

\section{Alumni relations}

These projects create strong ties to alumni, who continue to have interest in these projects. For many, it is a highlight of their school careers and few match the experience in their professional careers.

\section{Benefits to industry}

While the student design competitions do not directly solve industry problems, they provide important benefits to industry.

\section{Development of desired skills}

Many industry surveys show that employers are satisfied with the technical training of graduating engineers, but want to see non-technical skills improved. Many graduating engineers also lack practical knowledge. The design competitions develop many of those skills to a high level.

\section{Recruitment of engineers}

The automotive industry sponsors the SAE design competitions largely to ensure a continuing pool of top-notch engineering talent with suitable skills and attitudes. Many employers look for participation on these teams when hiring.

\section{Low-risk R\&D}

Many companies participate in motorsports as a way to develop and test new technologies and to increase brand awareness. Student design competitions provide many of these benefits at a very low cost. For example, the vehicles designed and built by the students are highly experimental, and typically incorporate innovative design features. Teams are constantly experimenting with alternative materials, components, fabrication methods, etc.

\section{Incorporating design competitions into the curriculum}

Under the right conditions, student design competitions provide a learning experience at least as rich as provided by traditional capstone design projects. In many cases, the educational value of the design competitions is significantly greater than for other projects. For example, few if any other capstone projects result in the construction and testing of a prototype of the sophistication of a Formula SAE or Mini-Baja vehicle. 


\section{Learning objectives}

Davis et al. [12] define desired learning outcomes of design education in terms of three dimensions:

- Design process - Defining, performing, and managing steps to create and deliver a technological product that meets or exceeds the needs of clients.

- Teamwork - Organizing and managing the activities and resources of multiple people to achieve results beyond what can be done individually.

- Design Communication - Exchanging and managing information needed to support effective design.

Student design competitions achieve these outcomes at least as well as conventional design projects.

\section{Assessment and evaluation}

An important question is how to assess and evaluate the achievement of learning objectives for academic credit. Conventional design courses are often carefully structured, with numerous milestones, formal reports, presentations, design reviews, etc., to evaluate student performance.

The design competitions typically have similar requirements, but the milestones and deadlines do not correspond to the academic timetable. Forcing these projects into the structure of an existing capstone design course can be problematic.

Davis et al. [12] propose a mechanism for assessing proficiency in each of the dimensions at different stages of a design project. Their assessment ranks proficiency and tracks progress, using a set of rubrics. This approach appears to be suitable for assessing megaprojects.

Evidence of proficiency in each of the dimensions can be assessed using design portfolios. These portfolios would constitute a collection of student work including communications and memos, design notebooks and journals, engineering drawings and CAD models, presentations, and reports. It is reasonable to require students to document what they have done on the project over the duration of the academic period, and to assign a grade based on this evidence.

\section{Role of the instructor}

Some might argue that credit cannot be given unless there is formal instruction. However, the role of the instructor in most capstone design courses is to act as an advisor, to define expectations, and to evaluate progress and achievement.

There is a general perception that teaching design requires more effort than teaching a normal lecture course. However, this does not need to be the case. At Western, there has been relatively little faculty involvement in the student design megaprojects, yet they have been very valuable learning experiences for students.

One important role for faculty is to recognize the conditions that are conducive to maximizing educational value, and to work to establish them. Allowing students to manage their own teams should be a conscious decision, not a byproduct of faculty apathy. If this is not understood, enthusiastic faculty could actually destroy the necessary conditions by becoming too involved!

\section{Resource Requirements}

The educational value of student design competitions seems clear. However, significant resources are required to support these megaprojects.

\section{Funding}

The design competitions involve the construction of much more sophisticated artifacts than is typical in traditional capstone design projects. For example, whereas a typical capstone project might involve the construction of a crude prototype from wood and scrap material, the megaproject teams construct high performance vehicles to standards more appropriate to industry than to student projects.

These professional-quality artifacts cannot be built from scrap materials using hand tools. As a result, significant resources are required, again commensurate with industrial practice.

Western's megaproject teams receive relatively little university funding, and engage in vigorous fundraising activities. Despite having significantly fewer resources than some competing schools, Western's teams usually perform well in competitions.

A typical operating budget for Western megaprojects is $\$ 10$ - \$20K per year per project. These funds are required to cover the following expenses: 
- Travel costs to attend competitions, including air fare, vehicle rental, accommodation, etc. Students often pay part of these costs themselves.

- Cost of purchased components and materials, including engines, shock absorbers, wheels, brakes, etc. Some of these components are donated.

- Cost of machine shop time. Many components are designed by the students. The proper machining and fabrication of these components is often beyond the capabilities of the students and their tools, and must by done by a qualified machine shop. Again, some but not all of the construction is donated by sponsors.

\section{Workshop space}

Construction of large, professional quality artifacts like vehicles requires suitable workshop space. In an industrial setting, such space would include high ceilings, large access doors to the outside, overhead gantry cranes, automotive hoists, workbenches and machine shop facilities.

Western students have demonstrated that it is possible to design and build high-quality artifacts with limited workshop facilities and space, but this is not an ideal situation.

Western has plans for the construction of a new student activity building to address this need.

\section{Workshop equipment and training}

Construction of professional quality artifacts requires a well equipped workshop with facilities for welding, machining, sheet metal fabrication, etc.

Even if a well equipped student machine shop were available, students do not have the skills and training to do complex, professional fabrication. In industry, engineers don't fabricate their designs themselves but work with highly skilled technicians. It is valuable for engineers to gain practical experience by both doing some basic fabrication themselves, and by working with and learning from expert technicians.

\section{Technicians}

It takes years of training, apprenticeship and experience to become an expert technician. It is not realistic to provide this training to engineering students. It is more appropriate to expose them to these skills and develop their appreciation for the important role of technicians.

It is important to have skilled technicians available to assist in construction of the design artifacts. Student megaprojects provide a wonderful opportunity for engineering students to interact with technicians in a realistic situation.

\section{Advisors}

Faculty involvement is required to support the megaproject teams, but the effort need not be great if a coaching approach is used rather than a controlling approach. Too much faculty involvement can become detrimental, as project ownership could shift from students to faculty and staff.

\section{Computers and design software}

Computers are used in all phases of design, and their use must be encouraged and supported for student design projects. Teams require access to computers and necessary design software including:

\section{- $\quad$ CAD modeling}

- Analysis including kinematics, FEA, CFD, etc.

- Manufacturing including rapid prototyping and CAM

Many of the components of the design artifacts can be CNC machined based on CAD models created by the students.

Common undergraduate computers with the necessary software should be available for these projects. Dedicated computer labs for project use are preferable as they can be configured specifically to suit the needs of these design projects rather than serving the needs of all undergraduate programs.

In addition to design software, student design teams need an industrial-grade computing infrastructure to support collaborative design. The infrastructure must support shared workspaces, shared document management, product data management (PDM), product lifecycle management (PLM), project management, etc. Suitable commercial systems exist, including Microsoft SharePoint, PTC Projectlink, Alibre Design, UGS Teamcenter, and others. To date, few engineering schools use these systems to support student design projects. It is important to expose students to the use of these tools in the design process. 


\section{Conclusions}

Student design competitions can be very effective in achieving desired learning outcomes compared to alternative design experiences. It is important that students maintain ownership of these projects, with faculty in an advisory role only. Adequate resources must be provided, and innovative assessment methods used, if these projects are to be incorporated into the curriculum.

\section{References}

[1] Criteria for Accrediting Engineering Programs, Effective for Evaluation of Programs During the 2003-2004

Accreditation Cycle, Accreditation Board for Engineering and Technology (ABET), Baltimore, MD, 2002.

[2] Accreditation Criteria and Procedures, Canadian Engineering Accreditation Board, Canadian Council of Professional Engineers, 2002.

[3] Manufacturing Education Plan: 1999 Critical Competency Gaps, Society of Manufacturing Engineers, Dearborn MI, 1999, accessed at www.sme.org/foundation/report-phase1_update.pdf

[4] Engineers for Business Excellence: Study among Canadian Auto Industry Engineering Managers, The Strategic Council, July 2002

[5] Ullman, David G.; The Mechanical Design Process, $3^{\text {rd }}$ Edition, McGraw-Hill, New York, 2003.

[6] Otto, Kevin; and Kirtin Wood, Product Design: Techniques in Reverse Engineering and New Product Development, Prentice Hall, Upper Saddle River, NJ, 2001.

[7] Dieter, George E., Engineering Design: A Materials and Processing Approach, $3^{\text {rd }}$ Edition, McGraw-Hill, New York, 2000.

[8] Farr, John V.; M. A. Lee; R. A. Metro, J. P. Sutton; "Using a Systematic Engineering Design Process to Conduct Undergraduate Engineering Management Capstone Projects”, Journal of Engineering Education, April 2001.

[9] Dutson, A. J.; R. H. Todd; S. P. Magleby; C. D. Sorensen, “A Review of Literature on Teaching Engineering Design Through Project-Oriented Capstone Courses”, Journal of Engineering Education, January 1999, pp.17-28.

[10] Catalano, G. D.; and K. L. Tonso, “The Sunrayce '95 Idea: Adding Hands-On Design to an Engineering Curriculum”, Journal of Engineering Education, July 1996, pp. $193-199$.

[11] Rencis, Joseph J., “The Formula SAE Racecar Project at WPI”, Proceedings of the 2000 ASEE Annual Conference, St. Louis MO, June 18 - 21, 2000, CD-ROM, 13 pages.
[12] Davis, Denny C.; K. L. Gentili; M. S. Trevisan ; R. K. Christianson ; J. F. McCauley ; Measuring Learning Outcomes for Engineering Design Education, Proceedings of the 2000 ASEE Annual Conference, St. Louis MO, June 18 21, 2000, CD-ROM, 7 pages. 